\title{
Dominican Republic, Haiti, Nicaragua: Women living with HIV have unmet family planning needs
}

Population Council

Follow this and additional works at: https://knowledgecommons.popcouncil.org/departments_sbsr-rh

Part of the Demography, Population, and Ecology Commons, Family, Life Course, and Society Commons, Gender and Sexuality Commons, International Public Health Commons, and the Medicine and Health Commons How does access to this work benefit you? Let us know!

\section{Recommended Citation}

"Dominican Republic, Haiti, Nicaragua: Women living with HIV have unmet family planning needs," FRONTIERS OR Summary. Washington, DC: Population Council, 2008. 


\section{DR, Haiti, Nicaragua Integration}

\section{OR Summary 75}

\section{Women Living with HIV Have Unmet Family Planning Needs}

\author{
Women living with HIV in the Dominican Republic, Haiti, and Nicaragua \\ are marginalized in many aspects, including their access to family plan- \\ ning services. Efforts should be made to link or coordinate family plan- \\ ning services with the health care of persons living with $\mathrm{HIV}$.
}

\section{Background}

Making family planning (FP) services accessible to persons living with HIV (PLWH) is one of the four key strategies that WHO promotes in its comprehensive approach to prevent HIV infections in infants and young children. ${ }^{1}$ This strategy also increases the coverage and quality of FP services among a population that is commonly underserved and at high risk of an unplanned pregnancy. Expanded access to antiretroviral therapy in many developing countries has improved the life expectancies and health of many PLWH who are resuming sexual activity and often need contraception. A recent FRONTIERS study in the Dominican Republic, Haiti, and Nicaragua shows that women living with HIV (WLWH) have an unmet need for FP. The lack of coordination between HIV and FP programs is a factor that contributes to this unmet need.

The data in this summary come from structured interviews with WLWH and receiving care in integral care units (ICUs) in the Dominican Republic (156) and Haiti (50), as well as the results of a focus group discussion with 13 WLWH in Nicaragua who were affiliated with ASONVIHSIDA, the Nicaraguan branch of the International Community of Women Living with HIV/AIDS. All the women in the study were of reproductive age (between ages 15 and 49). During these interviews information was gathered on women's

\footnotetext{
${ }^{1}$ World Health Organization. 2007. "Prevention of Mother-to-Child Transmission of HIV," HIV Technical Briefs. (http://www.who.int/reproductivehealth/hiv/hiv_tecbrief_pmtct.pdf) Accessed December 18, 2007
}

socio-demographic characteristics, fertility behavior and desires, past and current contraceptive use, access to reproductive health services, and the quality of the services received. To put the needs of ICU clients in context, we compared the socio-demographic characteristics of the women in our sample with those of all women of reproductive age in their country, as reflected in the latest Demographic and Health Survey available in each country.

\section{Findings}

- Women living with HIV and receiving care in integral care units shared many characteristics with women who often have limited access to family planning services. They tended to be older, less educated, and less likely to be living with a male partner than other women in reproductive age.

- Compared to all women in reproductive age, the WLWH interviewed were more likely to have children and to want to limit their fertility (see Table). Many WLWH had used contraceptives before, but discontinued use because they did not have a stable partner or were not having sexual relations frequently. In the Dominican Republic, contraceptive use among WLWH was 64 percent. Three-fourths of non-users had used a method before, and 69 percent of these women discontinued use because of infrequent sex or the lack of a stable partner. In Haiti, contraceptive use was 34 
percent. Twenty-one percent of non-contraceptive users had used family planning before, but stopped for the same reasons.

\begin{tabular}{|l|c|c|c|c|}
\hline \multicolumn{4}{|l|}{$\begin{array}{l}\text { Selected socio-demographic characteristics of Integral } \\
\text { Care Unit clients and all women of reproductive age in the } \\
\text { Dominican Republic and Haiti (\%) }\end{array}$} \\
\hline & \multicolumn{2}{|c|}{ Dominican Republic } & \multicolumn{2}{|c|}{ Haiti } \\
\cline { 2 - 5 } & $\begin{array}{c}\text { ICU } \\
\text { users } \\
(\mathrm{n}=156)\end{array}$ & $\begin{array}{c}\text { All women } \\
(\mathrm{n}=13,996)\end{array}$ & $\begin{array}{c}\text { ICU } \\
\text { users } \\
(\mathrm{n}=50)\end{array}$ & $\begin{array}{c}\text { All } \\
\text { women } \\
(\mathrm{n}=6,323)\end{array}$ \\
\hline Adolescent & 7 & 25 & 3 & 19 \\
\hline $\begin{array}{l}\text { Divorced, } \\
\text { separated or } \\
\text { widowed }\end{array}$ & 54 & 16 & 17 & 9 \\
\hline No education & N.A. & N.A. & 28 & 20 \\
\hline $\begin{array}{l}\text { Primary educa- } \\
\text { tion or less }\end{array}$ & 28 & 20 & N.A. & N.A. \\
\hline Have children & 96 & 72 & 74 & 60 \\
\hline $\begin{array}{l}\text { Do not want } \\
\text { any more } \\
\text { children }\end{array}$ & 83 & 66 & 76 & 57 \\
\hline
\end{tabular}

- Among WLWH who were not using a contraceptive because they did not have a stable partner, half of the Haitians and one-fifth of Dominicans reported having had sexual relations without using a condom during the past year.

- Though many WLWH want to use a contraceptive, they often do not receive one. Eight of every 10 women who were not using a contraceptive in Haiti said that they would like to use one. One-third of these reported that they requested a method but were not given one; 15 percent did not know what method to use, and the rest did not have a stable partner, or had been told to wait to recover strength before using a method.
- In Nicaragua, some women were advised to stop the use of other methods because providers deemed them unnecessary if condoms were used. However, women said that they did not feel completely safe using only condoms.

\section{Policy Implications}

- Providers involved in the general and reproductive health care of persons living with HIV should be sensitized about the needs of this population. They should also receive frequent updates of the contraceptive eligibility criteria and reminded that PLWH, like other clients, have a right to choose the contraceptive method that suits their needs.

- Efforts should be made to link or coordinate family planning services with the health care of PLWH. Integral Care Units, which generally tend all the health needs of women living with HIV, are not adequately meeting their family planning needs. Improving access to FP services among this population is an important strategy to reduce new HIV infections and to expand the coverage of family planning services in underserved populations.

Sources: Quiterio, Gisela et al. 2008. “Dominican Republic: Diagnostic study of postpartum, postabortion and PMTCT contraceptive services,” FRONTIERS Final Report. Washington, DC: Population Council. See Also: Rivero-Fuentes, Estela, Ricardo Vernon, Michaelle Boulos and Louis-Marie Boulos. 2008. "Haiti: Situation analysis of the use of contraception in postpartum, postabortion and prevention of mother-to-child HIV transmission," FRONTIERS Final Report. Washington, DC: Population Council. See Also: Solis, Freddy et al. 2008. "Situation analysis of the use of contraception in postpartum, postabortion, and prevention of mother-to-child transmission (PMTCT) programs, Nicaragua," FRONTIERS Final Report. Washington, DC: Population Council. Available on our website at www.popcouncil.org/frontiers or by e-mail: frontiers@popcouncil.org

This publication is made possible by the generous support of the American people through the United States Agency for International Development (USAID) under the terms of Cooperative Agreement No. HRN-A-00-98-00012-00. The contents are the responsibility of the FRONTIERS Program and do not necessarily reflect the views of USAID or the United States Government. 